\title{
Apple trees as a possible monitor and phytoremediator of urban and industrial areas in Chelyabinsk, Russian Federation
}

\author{
TATYANA G. KRUPNOVA ${ }^{1, \bullet}$, NATALIA L. NAUMOVA ${ }^{2}$, OLGA V. RAKOVA ${ }^{1}$, OLGA M. BURMISTROVA ${ }^{3}$, \\ EVGENY A. BURMISTROV ${ }^{3}$ \\ ${ }^{1}$ Department of Ecology and Chemical Engineering, Institute of Natural Sciences and Mathematics, South Ural State University. 76, Lenin Prospekt, \\ 454080 Chelyabinsk, Russia. Tel.: +7-9642444419, vemail: krupnovatg@ susu.ru \\ ${ }^{2}$ Department of Food Technology and Biotechnology, Higher School of Medicine and Biology, South Ural State University. 76, Lenin Prospekt, 454080 \\ Chelyabinsk, Russia \\ ${ }^{3}$ Department of Infectious Diseases and Veterinary and Sanitary Expertise, South Ural State Agrarian University. 13 Gagarin Street, 457100 Troitsk, \\ Chelyabinsk, Russia
}

Manuscript received: 12 April 2021. Revision accepted: 22 June 2021.

\begin{abstract}
Krupnova TG, Naumova NL, Rakova OV, Burmistrova OM, Burmistrov EA. 2021. Apple trees as a possible monitor and phytoremediator of urban and industrial areas in Chelyabinsk, Russian Federation. Biodiversitas 22: 2824-2828. Apple trees are cultivated worldwide and are the most widely grown fruit crops in the South Ural region. This study examines the suitability of apple trees for biomonitoring and phytoremediation. We collected the leaves and fruits of the apple (Malus domestica Borkh.) trees and the surrounding soil from three areas in Chelyabinsk, a typical Russian industrial city. The leaves, fruits and soils were analyzed for metal(loid) content (As, B, Cd, Co, Cr, Cu, Fe, Ga, In, Hg, Mn, Ni, Pb, Se, Sn, Sr, and Zn). The results were obtained using mass spectrometry with inductively coupled plasma (ICP-MS). We found a response in the apple tree defense system to the action of heavy metals in the synthesis of biologically active substances. The data gave information about the environmental state of soils collected in the zones of influence of metallurgical industrial enterprises. However, the trees did not assimilate or tolerate high concentrations of metal(loid)s in the leaves and they cannot be recommended for phytoremediation.
\end{abstract}

Keywords: biomonitoring, environmental soil quality, metal(loid)s, regression model

\section{INTRODUCTION}

The apple tree Malus domestica Borkh. is one of the most widely cultivated and economically important fruit crops in the South Ural region. Fresh apples contain sugars, organic acids, vitamins, micro- and macronutrients, fiber, lipids, wax, carotene, protein, furfural, essential oils, triterpenoids and pectin (Koutsos et al. 2015; Jang and Hyun 2016; Bondonno et al. 2018). Teas and tinctures from apple leaves are rich in flavonoids, tannins and organic acids. They are used in traditional medicine for the treatment of chills, rheumatism, gout, liver and kidney diseases, urinary tract (Saganuwan 2010).

Food gardening is important for over half of the Russian population during the summer period (from May to September) (Melnikov et al. 2020). Some Russians living in rural areas have a garden at their primary residence, while Russians living in cities often have a dacha located in the exurbs (Kallus 2016; Rusanov 2019). It is a piece of land allotted, normally free, to citizens by the local government for gardening. A dacha usually includes a dwelling and a garden where people grow fruit and vegetables; in the South Ural region apple trees are very popular. Dachas are often located a short distance from the urban area in zones polluted by industrial enterprises. The soils of these zones can be contaminated with heavy metals. Some studies demonstrated that various plant species grown on the same soils have different metal uptakes (Krupnova 2020a) and can be used for biomonitoring and phytoremediation.

The toxicity of metal(loid)s is based on their ability to bind to the thiol functional groups of biomolecules, which leads to a disruption of the structure and functioning of proteins, including enzymes. Oxidative stress is an important mechanism of metal toxicity and plants need antioxidants, such as flavonoids, to protect against such stress (Khozeeva et al. 2020). Biologically active substances are involved in many physiological processes, including photosynthesis, respiration, growth, and plant defenses. It is of interest for studying how plants (including food plants) react to anthropogenic factors (SkórzyńskaPolit et al. 2004).

Biomonitoring is the use of biological accumulators, such as plants, in a diagnostic study. This method is useful since the cost is low and it can be used efficiently on a large scale, offering a tool to monitor heavy metal contamination (Antonucci et al. 2016; Belguidoum et al. 2020, Belguidoum et al. 2021). Several higher plants have been used to assess metal contamination in urban and industrial area because of their accumulation properties (Vannucchi et al. 2020; Koucim et al. 2021, Giniatullin et al. 2016). This paper investigates the possibility to use apple trees to monitor and ameliorate the metal(loid) pollution of Chelyabinsk urban areas. The research (i) compares the metal(loid) concentrations in the soils, leaves and fruits of the "Prizemlennoye" apple variety, (ii) 
investigates the relationship between the level of metal(loid)s in soils and apple tree leaves and fruit, (iii) identifies the apple tree parts that can accumulate metal(loid)s and serve as bioindicators of urban pollution, and (4) studies the contents of individual biologically active substances in apples under anthropogenic influences.

\section{MATERIALS AND METHODS}

\section{Study area}

Chelyabinsk is industrial city located in the South Ural region. We chose three areas located in the zones of influence of three large Chelyabinsk industrial enterprises: the Chelyabinsk Metallurgical Plant, the Chelyabinsk Electrometallurgical Integrated Plant, and the Chelyabinsk Zinc Plant. We chose 15 sites located in three areas (Figure 1). Area 1 (55.203961 N, 61.468786E, 4 sites) was located in the east of city (zones of influence: the Chelyabinsk Metallurgical Plant and the Chelyabinsk Electrometallurgical Integrated Plant). Area 2 (55.286066 N, 61.396032E, 6 sites) was located in the north of the city (zone of influence: the Chelyabinsk Metallurgical Plant). Area $3(55.221291 \mathrm{~N}, 61.331865 \mathrm{E}, 5$ sites) was located in the west of Chelyabinsk (zone of influence: the Chelyabinsk Zinc Plant). In previous studies (Krupnova 2020b) a connection between the air pollution of these enterprises and urban greening was shown. At all sites, there is a dacha where Prizemlennoye apple trees were growing. This variety is characterized by winter hardiness, high productivity and scab resistance.

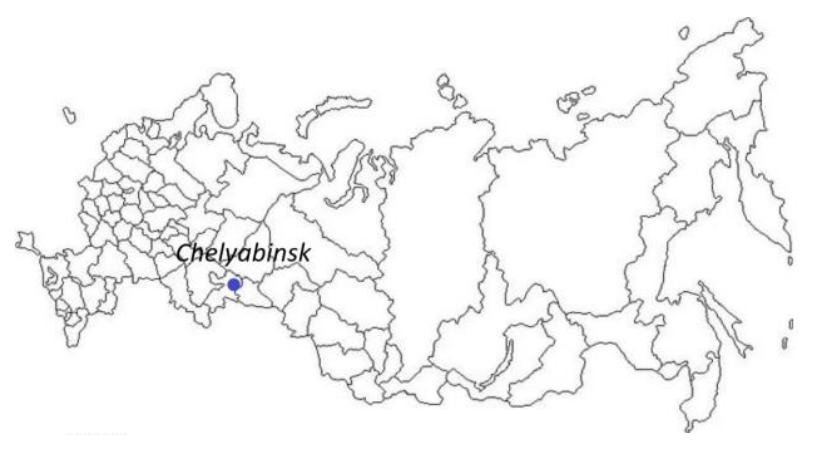

Chelyabinsk Metallurgi
Integrated Plant

Figure 1. Location of the sampling areas

\section{Procedures}

The samples were taken from the selected sites in September 2019, when the maximum metal(loid) uptake was expected. Soil samples were taken and dried in an oven at $60{ }^{\circ} \mathrm{C}$ for 3 days, and then crushed and sieved through a $1 \mathrm{~mm}$ polyethylene sieve to remove stones, coarse materials, and other debris. Urban soils are typically characterized by increased concentrations of metal(loid)s (Yusupov et al. 2017; Kasimov et al. 2019; Skugoreva et al. 2019; Krupnova et al. 2020b). Foliar absorption of metal(loid)s through the leaf plates occurs in addition to through the roots (Kasimov et al. 2019; Skugoreva et al. 2019; Krupnova et al. 2020b; Belguidoum et al. 2020; Medvedeva et al. 2021; Morton-Bermea et al. 2021). Plant material was taken from 2-5 adult apple trees at each site. Leaves and fruits ((about $50 \mathrm{mg})$ ) were taken from different quarters of canopy as recommended in (Wang et al. 2015; Tošić et al. 2016, Krupnova et al. 2020a; Łukowski et al. 2020). All leaf and fruit samples were washed in freshwater to eliminate dust, dirt and insects. The washed leaves were dried in an oven at $60{ }^{\circ} \mathrm{C}$ for 3 days, and then ground into powder. A freeze dryer was used for drying fruit samples. All samples (leaf powder, fruit and soil) were separately microwave digested with $65 \% \mathrm{HNO}_{3}$ acid (Krupnova et al. 2018). After cooling, the solution was filtered through blue-ribbon filter paper and deionized water was added to make a volume of $50 \mathrm{ml}$. The solutions were analyzed for metal(loid)s content (As, B, $\mathrm{Cd}, \mathrm{Co}, \mathrm{Cr}, \mathrm{Cu}, \mathrm{Fe}, \mathrm{Ga}, \mathrm{In}, \mathrm{Hg}, \mathrm{Mn}, \mathrm{Ni}, \mathrm{Pb}, \mathrm{Se}, \mathrm{Sn}, \mathrm{Sr}$, and $\mathrm{Zn}$ ) by mass spectrometry with inductively coupled plasma ICP-MS using iCAP 7200 DUO. The analyses were performed in triplicates.

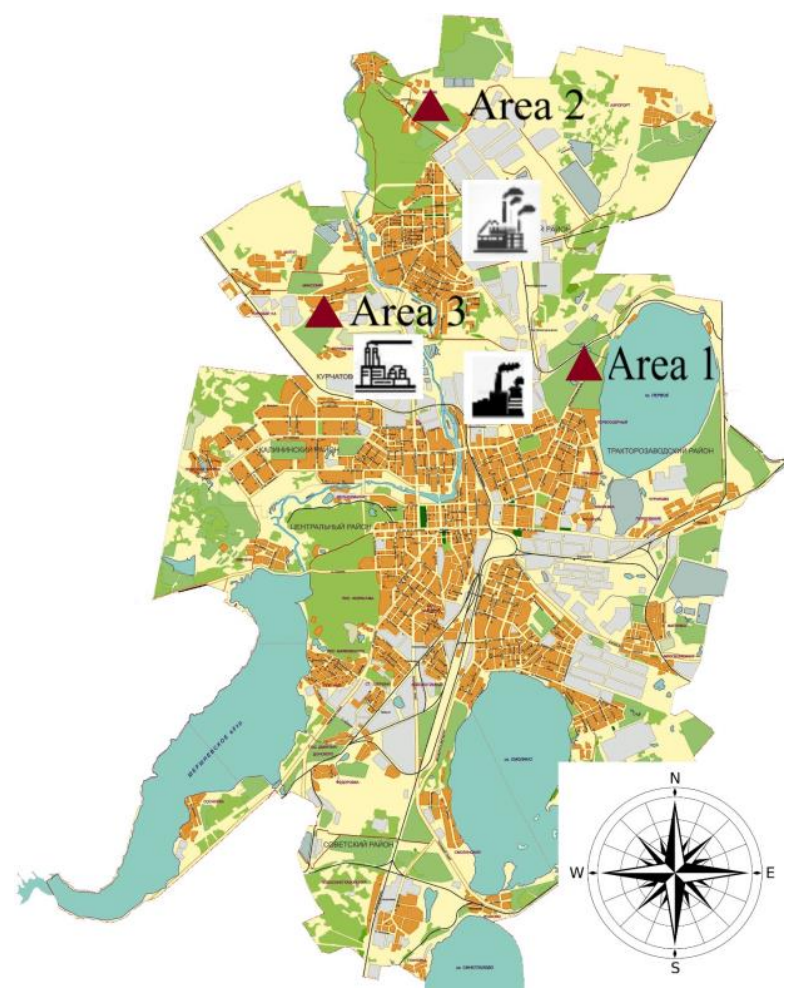


The Russian national state standard samples (Vinogradov Institute of Geochemistry SB RAS, Russia) of birch leaves (GSO 8923-2007) and a mixture of herbs (GSO 8922-2007) were used to check the accuracy of the metal(loid) content in leaves and fruits. The certified reference material (CRM) GSO 10413-2014 CO of the structure (agrochemical indicators) of Umbric Albeluvisols Abruptic (SADPP-10) was obtained from I BEND Rosselkhozakademiya's VNIIA (Russia). The recoveries for metal(loid) content in the CRMs of soil and plant samples ranged from $87 \%$ to $119 \%$.

The sugar content in fruits was determined by capillary electrophoresis; vitamin $\mathrm{C}$ by the titrimetric method; flavonoids (rutin) by the spectrophotometric method.

\section{Data analysis}

Microsoft Excel 2013 and SPSS 27.0 software were used to organize and analyze the data. Differences in metal(loid) concentrations in the 15 sites were analyzed using ANOVA with post-hoc comparisons using Fisher's (Meier 2006) least significant difference (LSD).

\section{RESULTS AND DISCUSSION}

The metal(loid) concentrations in the soils are presented in Table 1. The distribution of heavy elements was: $\mathrm{Fe}>\mathrm{Mn}>\mathrm{Zn}>\mathrm{Sr}>\mathrm{Ni}>\mathrm{Pb}>\mathrm{Cr}>\mathrm{Cu}>\mathrm{B}>\mathrm{Co}>\mathrm{In}=\mathrm{As}>\mathrm{Sn}>\mathrm{Cd}>\mathrm{Se}$ $>\mathrm{Ga}>\mathrm{Hg}$. Concentrations of metal(loid)s did not exceed the maximum allowed concentrations (MACs) according to the Russian National standards of environmental soil quality. $\mathrm{Ga}$ and In were present only in soils from Area 3. In this case, the concentration of In was 27 times higher than its average content in the upper continental crust. The main source of $\mathrm{Ga}$ and $\mathrm{In}$ is the Chelyabinsk Zinc Plant (see Fig.1) as Ga and In are contained in the zinc-lead ores used for zinc production.

Due to the anthropogenic impact, the soils were characterized by a concentration of $\mathrm{Cd} 10$ times higher than the average content of the upper continental crust; $\mathrm{Pb}, \mathrm{Se}$, $\mathrm{Ni}$ and $\mathrm{Zn} 2-4$ times higher; and $\mathrm{Cu}$ and $\mathrm{B}$ 1.1-1.2 times higher. The detected amounts of $\mathrm{Cd}, \mathrm{Cu}, \mathrm{B}, \mathrm{Pb}, \mathrm{Se}, \mathrm{Ni}$ and $\mathrm{Zn}$ may be considered phytotoxic (Kabata-Pendias and Pendias 2001). Other elements (Ti, V, Cr, Mn, Fe, Co, Ni, As, and La) did not accumulate in soils (Table 1). For most metal(loid)s, the concentrations in soils between the three Areas showed significant differences. For example, the concentration of $\mathrm{Ni}$ was the highest in Area 1 and excess Clarke values were observed only for Area 3.

Compared to soils, the apple tree tissues contained less metal(loid)s with clear variations among different areas (Table 2). The content of $\mathrm{Cd}, \mathrm{Cr}$ and $\mathrm{Pb}$ in the fruit exceeded the limits according to Technical Regulation "On food safety" (TR). The contents of As, $\mathrm{Hg}$ and $\mathrm{Sn}$ were safe in apples. Acceptable levels of other elements are not standardized in Russian or EU legislation (TR CU 021/2011, 2011). Our previous work (Krupnova 2020b) showed that there was an extremely high $\mathrm{Zn}$ content (316-
$4000 \mu \mathrm{g} \mathrm{g}^{-1}$ ) in birch leaves collected in Chelyabinsk. The $\mathrm{Zn}$ content in apple leaves was much lower $\left(27-78 \mu \mathrm{g} \mathrm{g}^{-1}\right)$. The $\mathrm{Zn}$ content in apple leaves correlates well with its content in the soil (Table 3). Whereas in birch leaves $\mathrm{Zn}$ did not correlate with the soil content (Krupnova 2020b). This indicates that $\mathrm{Zn}$ accumulation from soil was the dominant pathway for apple trees. The extremely high $\mathrm{Zn}$ concentration in birch leaves was associated with foliar uptake of Zn-containing particulate matter (PM) suspended in the air. Many characteristics, such as surface roughness, trichomes, and a wax layer affect uptake of metals (Lukowski et al. 2020). Silver birch (Betula pendula) accumulated the most PM compared to other tree species because it has the largest amounts of epicuticular wax on its leaves. The smooth surface of apple leaves is the main reason for its lower PM accumulation. Apple trees did not accumulate extreme concentrations of metals in their above-ground parts. We can not write that apple trees are hyperaccumulators;

Table 3 indicates that the metal(loid)s found in the leaves and fruit correlate significantly with those found in soils at the 0.001 significance level. It was except for $\mathrm{Sr}$ and $\mathrm{Co}$ in soils and fruits which correlate at the 0.05 significance level, and $\mathrm{Co}$ in soil and leaves, which correlate at the 0.01 significance level. There were no significant correlations between $\mathrm{Cd}$ in soils and leaves and fruits, or $\mathrm{Fe}$ and $\mathrm{Sr}$ in soils and leaves. The correlation depends on the bioavailability of metals in soils influenced by the total metal concentration, $\mathrm{pH}$, the organic matter content, redox conditions, and the presence of clays and hydrous oxides (Wang et al. 2015). The results obtained from the Pearson correlation coefficient analysis show that the apple tree can be useful for identification of differences in soil metal(loid) levels.

Table 3. The Pearson correlation coefficient between metal(loid) concentrations in soil and leaves, and in soils and fruits

\begin{tabular}{lll}
\hline \multirow{2}{*}{ Metal(loid) } & \multicolumn{2}{l}{ Pearson correlation coefficient } \\
\cline { 2 - 3 } & Soil-leaves & Soil-apple \\
\hline $\mathrm{As}$ & $0.836^{* * *}$ & $0.856^{* * *}$ \\
$\mathrm{~B}$ & $0.816^{* * *}$ & $0.850^{* * *}$ \\
$\mathrm{Cd}$ & 0.355 & 0.165 \\
$\mathrm{Co}$ & $0.533^{*}$ & $0.662^{* *}$ \\
$\mathrm{Cr}$ & $0.990^{* * *}$ & $0.967 * * *$ \\
$\mathrm{Cu}$ & $0.980^{* * *}$ & $0.970^{* * *}$ \\
$\mathrm{Fe}$ & 0.065 & $0.851^{* * *}$ \\
$\mathrm{Ga}$ & $0.978^{* * *}$ & $0.990^{* * *}$ \\
$\mathrm{Mn}$ & $0.920^{* * *}$ & $0.924^{* * *}$ \\
$\mathrm{Ni}$ & $0.990^{* * *}$ & $0.936^{* * *}$ \\
$\mathrm{~Pb}$ & $0.990^{* * *}$ & $0.936^{* * *}$ \\
$\mathrm{Se}$ & $0.736^{* * *}$ & $0.844^{* * *}$ \\
$\mathrm{Sn}$ & $0.824 * * *$ & $0.926^{* * *}$ \\
$\mathrm{Sr}$ & 0.313 & $0.711^{* *}$ \\
$\mathrm{Zn}$ & $0.860^{* * *}$ & $0.976^{* * *}$ \\
\hline $\mathrm{Note} *$ Correlation is significant at the 0.05 level ** Correlation
\end{tabular}

Note: * Correlation is significant at the 0.05 level. ** Correlation is significant at the 0.01 level. $* * *$ Correlation is significant at the 0.001 level. 
Table 1. Mean values ( \pm standard errors), maximum allowed concentrations (MACs) for metal(loid)s in the soil, and Clarke values in the upper continental crust $\left(\mu \mathrm{g} \mathrm{g}^{-1}\right)$. a, b, c indicate significant differences among the Areas according to Fisher's LSD (p < 0.05).

\begin{tabular}{|c|c|c|c|c|c|}
\hline \multirow{2}{*}{ Metal(loid) } & \multirow{2}{*}{$\operatorname{MAC}\left(\mu g g^{-1}\right)$} & \multirow{2}{*}{$\begin{array}{c}\text { Clarke (Rudnick and } \\
\text { Gao 2003) }\left(\mu \mathrm{g} \mathrm{g}^{-1}\right)\end{array}$} & \multicolumn{3}{|c|}{ Concentrations $\left(\mu \mathrm{g} \mathrm{g}^{-1}\right)$} \\
\hline & & & Area 1 & Area 2 & Area 3 \\
\hline As & $2(\mathrm{GN} 2.1 .7 .2041-06)$ & 4.8 & $1.60 \pm 0.07 \mathrm{a}$ & $1.71 \pm 0.05 \mathrm{a}$ & $1.30 \pm 0.02 \mathrm{~b}$ \\
\hline B & & 17 & $20 \pm 2 a$ & $23 \pm 2 a$ & $14 \pm 1 b$ \\
\hline $\mathrm{Cd}$ & & 0.09 & $1.12 \pm 0.04 \mathrm{a}$ & $0.92 \pm 0.02 c$ & $1.02 \pm 0.03 b$ \\
\hline Co & 50 (Ilyin 2012) & 18.3 & $10.4 \pm 0.9 a$ & $12.9 \pm 0.7 \mathrm{~b}$ & $13.3 \pm 0.9 \mathrm{c}$ \\
\hline $\mathrm{Cr}$ & 100 (Ilyin 2012) & 92 & $45 \pm 3 a$ & $58 \pm 4 b$ & $41 \pm 4 a$ \\
\hline $\mathrm{Cu}$ & 55 (GN 2.1.7.2041-06) & 28 & $33 \pm 2 a$ & $44 \pm 4 b$ & $30 \pm 2 a$ \\
\hline $\mathrm{Fe}$ & & 39200 & $25800 \pm 300 \mathrm{a}$ & $30000 \pm 300 \mathrm{~b}$ & $21800 \pm 300 b$ \\
\hline $\mathrm{Ga}$ & & 17.5 & $\mathrm{ND}^{* * * *}$ & $\mathrm{ND}^{* * * *}$ & $0.31 \pm 0.02$ \\
\hline In & & 0.056 & $\mathrm{ND}^{* * *}$ & $\mathrm{ND}^{* * * *}$ & $1.63 \pm 0.03$ \\
\hline $\mathrm{Hg}$ & & 0.05 & $0.17 \pm 0.02 \mathrm{a}$ & $0.19 \pm 0.02 \mathrm{a}$ & $0.07 \pm 0.01 \mathrm{~b}$ \\
\hline $\mathrm{Mn}$ & $1,500(\mathrm{GN} 2.1 .7 .2041-06)$ & 774 & $740 \pm 40 \mathrm{a}$ & $420 \pm 20 b$ & $230 \pm 10 \mathrm{c}$ \\
\hline $\mathrm{Ni}$ & $80(\mathrm{GN} 2 \cdot 1.7 .2041-06)$ & 47 & $103 \pm 10 \mathrm{a}$ & $35 \pm 3 b$ & $40 \pm 3 b$ \\
\hline $\mathrm{Pb}$ & $32(\mathrm{GN} 2.1 .7 .2041-06)$ & 17 & $94 \pm 5 \mathrm{a}$ & $50 \pm 4 b$ & $53 \pm 3 b$ \\
\hline $\mathrm{Se}$ & $10(\mathrm{GN} 2.1 .7 .2041-06)$ & 0.09 & $0.32 \pm 0.02 \mathrm{a}$ & $0.41 \pm 0.03 b$ & $0.30 \pm 0.02 \mathrm{a}$ \\
\hline $\mathrm{Sn}$ & & 2.1 & $1.33 \pm 0.03 \mathrm{a}$ & $1.17 \pm 0.02 b$ & $0.99 \pm 0.02 \mathrm{c}$ \\
\hline $\mathrm{Sr}$ & & 320 & $170 \pm 30 \mathrm{a}$ & $170 \pm 30 a$ & $170 \pm 30 \mathrm{a}$ \\
\hline $\mathrm{Zn}$ & $300(\mathrm{GN} 2.1 .7 .2041-06)$ & 67 & $320 \pm 20 b$ & $230 \pm 20 \mathrm{c}$ & $410 \pm 20 \mathrm{a}$ \\
\hline
\end{tabular}

Note: $\mathrm{ND}=$ not detected

Table 2. Mean values ( \pm standard errors) for metal(loid)s in the tissues of apple trees, and limits according to Technical Regulation "On food safety" (L) (TR) $\left(\mu \mathrm{g} \mathrm{g}^{-1}\right)$

\begin{tabular}{|c|c|c|c|c|c|c|c|}
\hline \multirow{3}{*}{ Metal(loid) } & \multirow{3}{*}{$\underset{\left(\mu \mathrm{g} \mathrm{g}^{-1}\right)}{\mathbf{L}}$} & \multicolumn{6}{|c|}{ Concentrations $\left(\mu \mathrm{g} \mathrm{g}^{-1}\right)$} \\
\hline & & \multicolumn{2}{|c|}{ Area $1(n=4)$} & \multicolumn{2}{|c|}{ Area $2(n=6)$} & \multicolumn{2}{|c|}{ Area $3(n=5)$} \\
\hline & & Leaves & Fruit & Leaves & Fruit & Leaves & Fruit \\
\hline As & 0.2 & $0.011 \pm 0.003$ & $0.009 \pm 0.001$ & $0.022 \pm 0.003$ & $0.015 \pm 0.002$ & $0.008 \pm 0.001$ & $0.007 \pm 0.001$ \\
\hline B & NS & $1.25 \pm 0.09$ & $1.06 \pm 0.05$ & $1.52 \pm 0.07$ & $1.31 \pm 0.08$ & $1.19 \pm 0.09$ & $0.98 \pm 0.05$ \\
\hline $\mathrm{Cd}$ & 0.03 & $0.074 \pm 0.005$ & $0.062 \pm 0.004$ & $0.083 \pm 0.006$ & $0.065 \pm 0.005$ & $0.058 \pm 0.003$ & $0.048 \pm 0.003$ \\
\hline Co & NS & $0.19 \pm 0.03$ & $0.10 \pm 0.02$ & $0.30 \pm 0.04$ & $0.16 \pm 0.03$ & $0.21 \pm 0.03$ & $0.12 \pm 0.02$ \\
\hline $\mathrm{Cr}$ & 0.5 & $1.5 \pm 0.1$ & $1.5 \pm 0.1$ & $2.2 \pm 0.2$ & $2.4 \pm 0.2$ & $1.3 \pm 0.1$ & $1.4 \pm 0.1$ \\
\hline $\mathrm{Cu}$ & NS & $7.1 \pm 0.5$ & $11.8 \pm 0.8$ & $27 \pm 1$ & $49 \pm 3$ & $7.9 \pm 0.4$ & $15 \pm 1$ \\
\hline $\mathrm{Fe}$ & NS & $400 \pm 10$ & $80 \pm 3$ & $230 \pm 7$ & $71 \pm 2$ & $241 \pm 6$ & $80 \pm 4$ \\
\hline $\mathrm{Ga}$ & NS & ND & ND & ND & ND & $0.12 \pm 0.02$ & $0.07 \pm 0.01$ \\
\hline In & NS & ND & ND & ND & ND & $0.60 \pm 0.04$ & $0.46 \pm 0.03$ \\
\hline $\mathrm{Hg}$ & 0.02 & $0.012 \pm 0.002$ & $0.011 \pm 0.002$ & $0.016 \pm 0.003$ & $0.014 \pm 0.002$ & $0.005 \pm 0.001$ & $0.004 \pm 0.001$ \\
\hline Mn & NS & $32 \pm 2$ & $12 \pm 1$ & $28 \pm 1$ & $9.9 \pm 0.3$ & $16.9 \pm 0.9$ & $4.7 \pm 0.2$ \\
\hline $\mathrm{Ni}$ & NS & $23 \pm 1$ & $7.1 \pm 0.2$ & $6.8 \pm 0.2$ & $2.48 \pm 0.08$ & $10.5 \pm 0.1$ & $4.9 \pm 0.3$ \\
\hline $\mathrm{Pb}$ & 0.5 & $8.5 \pm 0.2$ & $3.6 \pm 0.2$ & $5.2 \pm 0.1$ & $3.0 \pm 0.2$ & $5.2 \pm 0.3$ & $2.70 \pm 0.09$ \\
\hline $\mathrm{Se}$ & NS & $0.041 \pm 0.004$ & $0.026 \pm 0.002$ & $0.045 \pm 0.003$ & $0.031 \pm 0.002$ & $0.017 \pm 0.004$ & $0.015 \pm 0.002$ \\
\hline Sn & 200 & $0.112 \pm 0.007$ & $0.090 \pm 0.005$ & $0.117 \pm 0.006$ & $0.088 \pm 0.005$ & $0.076 \pm 0.004$ & $0.072 \pm 0.002$ \\
\hline $\mathrm{Sr}$ & NS & $113 \pm 4$ & $14 \pm 1$ & $40 \pm 2$ & $18 \pm 1$ & $115 \pm 4$ & $15.7 \pm 0.9$ \\
\hline $\mathrm{Zn}$ & NS & $78 \pm 4$ & $34 \pm 3$ & $27 \pm 2$ & $21 \pm 2$ & $79 \pm 4$ & $68 \pm 329$ \\
\hline
\end{tabular}

Note: $\mathrm{ND}=$ not detected. NS = not standardized. Bold values exceed TR limits.

Table 4. Quantitative characteristics of biologically active substances of the generative organs of the apple tree

\begin{tabular}{llll}
\hline \multirow{2}{*}{ Biologically active substance } & \multicolumn{3}{c}{ Value } \\
\cline { 2 - 4 } & Area 1 & Area 2 & \multicolumn{1}{c}{ Area 3 } \\
\hline Sugar content $(\%)$ & $10.5 \pm 0.5$ & $12.0 \pm 0.3$ & $14.3 \pm 0.4$ \\
Vitamin C content $\left(\mathrm{mg} 100 \mathrm{~g}^{-1}\right)$ & $13.2 \pm 0.6$ & $12.5 \pm 0.4$ & $15.8 \pm 0.3$ \\
Flavonoid content (rutin) $(\mathrm{mg}$ & $0.37 \pm 0.01$ & $0.64 \pm 0.02$ & $0.42 \pm 0.02$ \\
$\left.\mathrm{~g}^{-1}\right)$ & & & \\
\hline
\end{tabular}

The biologically active substances in apples were also investigated. The highest sugar $(14.3 \%)$ and vitamin C
(15.8 mg $\left.100 \mathrm{~g}^{-1}\right)$ content were in apples harvested in Area 3 (Table 4). This was associated with the relatively lower anthropogenic load on trees. Apples grown in Area 2 had the highest content of flavonoids $\left(0.64 \mathrm{mg} \mathrm{g}^{-1}\right)$ (Table 4). That was due to the large pollution of Area 2. The intake of pollutants in fruit tissues caused oxidative stress and the flavonoid content increased in response to this. The accumulation of flavonoids in response to environmental stress is a nonspecific reaction of plants and can be used as part of comprehensive biochemical monitoring of environmental problems. 
HMs found in the leaves and fruits of apple trees correlate significantly with those found in the soils. It confirms that all studied organs of apple trees can be useful for biomonitoring. Metal(loid)s may enter the soil and tree tissue from the metallurgical enterprises located in the Chelyabinsk urban area. We have found a response in the apple tree defense system to the action of heavy metals in the synthesis of biologically active substances, including flavonoids. The consumption of fruit grown near industrial enterprises can be hazardous due to elevated $\mathrm{Cd}, \mathrm{Cr}$, and $\mathrm{Pb}$ levels. However, hyperaccumulation was not recorded and apple trees cannot be recommended as phytoremediators of air pollution. The studied apple tree can be considered as an excellent biomonitor for atmospheric pollution in industrial zones.

\section{ACKNOWLEDGEMENTS}

South Ural State University thanks to the Ministry of Science and Higher Education of the Russian Federation (government order FENU-2020-0022).

\section{REFERENCES}

Antonucci A, Vitali M, Avino P, Manigrasso M, Protano C. 2016 Sensitive multi-residue method by HS-SPME/GC-MS for 10 volatile organic compounds in urine matrix: A new tool for biomonitoring studies on children. Anal Bioanal Chem 408 (21): 5789-5800. DOI: 10.1007/s00216-016-9682-x.

Belguidoum A, Lograda T, Ramdani M. 2020. Heavy metals accumulation in Hertia cheirifolia along the highway in Setif region, Algeria. Biodiversitas 21 (6): 2786-2793. DOI: 10.13057/biodiv/d210655

Belguidoum A, Lograda T, Ramdani M. 2021. Ability of metal trace elements accumulation by Lichens, Xanthoria parietina and Ramalina farinacea, in Megres area (Setif, Algeria). Sciendo 8 (1): 91-108. DOI: 10.2478/asn-2021-0008.

Bondonno NP, Bondonno CP, Blekkenhorst LC et al. 2018. FlavonoidRich apple improves endothelial function in individuals at risk for cardiovascular disease: A randomized controlled clinical trial. Mol Nutr Food Res 62 (3): 1700674. DOI:10.1002/mnfr.201700674.

Giniatullin RH, Ibragimova AH. 2016. Intensity of biological absorption of heavy metals in bodies of a birch (Betula pendula Roth), the conditions of industrial pollution. J For 20 (2): 74-80.

GN 2.1.7.2041-06. 2006. Maximum allowed concentrations (MACs) and approximate permissible concentration (APC) of chemical substances in the soil. Moscow. [Rusian]

Ilyin VB. 2012. Heavy Metals and Non-Metals in The Soil-Plant System. Publishing SO RAN, Novosibirsk. [Russian]

Jang K-II, Hyun TK. 2016. Apple as a source of dietary phytonutrients: an update on the potential health benefits of apple. EXCLI J 15: 565569. DOI:10.17179/excli2016-483.

Kabata-Pendias A, Pendias H. 2001. Trace Elements in Soils and Plants CRC Press LLC, Boca Raton, FL.

Kallus R. 2016. The dacha: Home away from home. J Archit Plann Res 33 (4): 271-292.

Kasimov NS, Bezberdaya LA, Vlasov DV, Lychagin MY. 2019. Metals, metalloids, and benzo[a]pyrene in PM10 particles of soils and road dust of Alushta City. Eurasian Soil Sci 52 (12): 1608-1621. DOI: 10.1134/S1064229319120068.

Khozeeva EV, Zimina YuA, Sroslova GA. 2020. Oxidative stress of plants: chemistry, physiology, methods of protection. Nat Syst Resour 10 (4): 30-43. DOI: 10.15688/nsr.jvolsu.2020.4.4
Koucim MA, Belguidoum A, Lograda T, Ramdani M. 2021. Heavy metals accumulation in Nerium oleander leaves across urban areas in Setif region, Algeria. Biodiversitas 22 (6): 3083-3091. DOI: 10.13057/biodiv/d220610

Koutsos A, Tuohy KM, Lovegrove JA. 2015. Apples and cardiovascular healthiest the gut microbiota a core consideration? Nutrients 7 (6): 3959-3998. DOI: 10.3390/nu7063959.

Krupnova TG, Mashkova IV, Scalev ED, Egorov NO, Gavrilkina SV. 2018. Concentrations of metal(loid)s in outdoor and indoor dust from Russian City. Intl J GEOMATE 15 (52): 30-37. DOI: 10.21660/2018.52.8197.

Krupnova TG, Rakova OV, Plaksina AL, Gavrilkina SV, Baranov EO, Abramyan AD. 2020a. Short communication: Effect of urban greening and land use on air pollution in Chelyabinsk, Russia. Biodiversitas 21 (6): 2716-2720. DOI: 10.13057/biodiv/d210646.

Krupnova TG, Rakova OV, Gavrilkina SV, Antoshkina EG, Baranov EO, Dmitrieva AP, Somova AV. 2020b. Extremely high concentrations of zinc in birch tree leaves collected in Chelyabinsk, Russia. Environ Geochem Health. DOI:10.1007/s10653-020-00605-3.

Łukowski A, Popek R, Karolewski P. 2020. Particulate matter on foliage of Betula pendula, Quercus robur, and Tilia cordata: deposition and ecophysiology. Environ Sci Poll Res 27: 10296-10307. DOI: 10.1007/s11356-020-07672-0.

Meier U. 2006. A note on the power of Fisher's least significant difference procedure. Pharm Stat 5 (4): 253-263. DOI: 10.1002/pst.210.

Medvedeva Yu, Kucher A, Lipsa J, Hełdak M. 2021. Human health risk assessment on the consumption of apples growing in urbanized areas: Case of Kharkiv, Ukraine. Intl J Environ Res Public Health 18 (4): 1504. DOI: 10.3390/ijerph18041504.

Melnikov AB, Mikhaylushkin PV, Ischenko NV. 2020. The role of horticultural products in ensuring food security in Russia. Intl Agric J 6 (378): 8-10. DOI: 10.24411/2587-6740-2020-16105.

Morton-Bermea O, Hernández-Álvarez E, Ordoñez-Godínez SL, MontesÁvila I. 2021. Mercury, platinum, antimony and other trace elements in the atmospheric environment of the urban area of Mexico City: Use of Ficus benjamina as biomonitor. Bull Environ Contam Toxicol 106 (4): 665-669. DOI: 10.1007/s00128-020-03080-9.

Rudnick RL, Gao S. 2003. Composition of the continental crust. Crust 3: 1-64. DOI: 10.1016/B0-08-043751-6/03016-4.

Rusanov AV. 2019. Dacha dwellers and gardeners: garden plots and second homes in Europe and Russia. Popul Econ 3 (1): 107-124. DOI: 10.3897/popecon.3.e34783.

Saganuwan AS. 2010. Some medicinal plants of Arabian Peninsula. Res J Med Plant 4 (9): 766-788. DOI: 10.5897/JMPR10.001

Skórzyńska-Polit E, Drązkiewicz M, Wianowska D, Maksymiec W, Dawidowicz AL, Tukiendorf A. 2004. The influence of heavy metal stress on the level of some flavonols in the primary leaves of Phaseolus coccineus. Acta Physiol Plant 26 (3): 247-254. DOI: 10.1007/s11738-004-0014-y.

Skugoreva SG, Kutyavina TI, Ogorodnikova SY et al. 2019. Integrated approach to environmental assessment of urban soil. Theor App Ecol 2019 (3): 57-65. DOI: 10.25750/1995-4301-2019-3-057-065.

Tošić S, Alagić S, Dimitrijević M, Pavlović A, Nujkić M. 2016. Plant parts of the apple tree (Malus spp.) as possible indicators of heavy metal pollution. Ambio 45 (4): 501-512. DOI:10.1007/s13280-0150742-9

TR CU 021/2011. 2011. TR on safety of food products.

Vannucchi F, Traversari S, Raffaelli A, Francini A, Sebastiani L. 2020. Populus alba tolerates and efficiently removes caffeine and zinc excesses using an organ allocation strategy. Plant Growth Regul 92 (3): 597-606. DOI: 10.1007/s10725-020-00664-7.

Wang Q, Liu J, Cheng Sh. 2015. Heavy metals in apple orchard soils and fruits and their health risks in Liaodong Peninsula, Northeast China. Environ Monit Assess 187 (1): 4178. DOI: 10.1007/s10661-0144178-7.

Yusupov DV, Bolshunova TS, Mezhibor AM, Rikhvanov LP, Baranovskaya NV. 2017. The use of Betula pendula R. Leaves for the assessment of environmental pollution by metals around tailings from a gold deposit (Western Siberia, Russia). Intl Multidisciplinary Sci GeoConference Surveying Geology and Mining Ecology Management, SGEM 17 (41): 665-672. DOI: 10.5593/sgem2017/41/S19.083. 